\section{Poisonous and Harmful Fishes of Australia}

G. P. WHImLEY has produced a most useful guide to all the poisonous and harmful fishes likely to be encountered in Australia, New Guinea and the islands of the south-west Pacific (Bulletin No. 159, Council for Scientific and Industrial Research. Commonwealth of Australia. Division of Fisheries, Report No. 10, 1943). This work will bo useful to members of the Allied Forces who may be unfamiliar with the fishes of these regions, many of which, although attractive in appearance, are very poisonous if eaten, while others prossess spines in connexion with poison glands which, if encountered, may cause great pain. The report is well illustrated by coloured and uncoloured figures, and the descriptions are written in non-technical language. Simple methods of treatment for food poisoning and for wounds from venomous fishes are included, and there are also hints for collectors who may wish to preserve specimens. A more detailed and technical work with full bibliography on the same subject is to be publishedshortly.

\section{Mediterranean Culture}

In his Fraser Lecture under this title (Cambridge : At the University Press. Pp. 52. 2s. net) Sir John Myres deals with a culture which developed in "an exceptional human habitat". He analyses first the permanent features of the mode of life of the ordinary dwellers in this Mediterranean area. Here is a peasantry closely adapting itself to the possibilities which the environment offered, and a wider community drawing from outside, since "in a region so physically uniform it was necessary to go far for anything unusual". Hence the significance of the sea, and with it sea-power shown legitimately in commerce, colonization, and pilgrimage, and otherwise in piracy. Hence, too, the gulf between the city, product of this sea-life, and the peasantry, a gulf that "has become an enduring fact of Medi. terranean life" ; and on all, immigrants have made their influence felt. Sometimes they have been "transformed by transit through the mountain zone", sometimes they have disorganized life for a time, but only for a time, since "the primary economic groups persist or re-appear". This summary analysis, to quote the author, "if not quite historical geography is offered as an essay in geographical history". Many' will derive pleasure and profit from what is thus offered.

\section{Inter-Allied Charter of Health}

The Anglo-Czechoslovak Founders Committee is offering a series of prizes for the lest essays on an Inter-Allied Charter of Health. The subjects for consideration in the essays are : (1) the study and survey of post-war relief schemes and other measures for health planning; and (2) the draft of a project to implement Article 6 of the Atlantic Charter with reference to health. A competitor may deal with these subjects separately or jointly. The competition is open to all medical men, public health experts, biologists and other workers in services connected with health. The minimum prize will be $£ 30$, the maximum to be determined later. The final date of entry is December 31. The Council for Education in World Citizenship, in collaboration with the AngloCzechoslovak Founders' Committee, proposes instituting a parallel competition in British and Allied schools in Great Britain. Further information can be obtained from the Health Charter Study Group, c/o Czechoslovak Institute, 18 Grosvenor Place, S.W.1.

\section{Royal Society of Edinburgh: New Officers}

AT the annual meeting of the Royal Society of Edinburgh held on October 25, the following officers were elected: President, Prof. E. T. Whittaker ; Vice-Presidents, Dr. James Watt, Prof. T. H. Milroy, Sir John Boyd Orr, Dr. A. W. Greenwood, Prof. E. Hindle, Dr. D. Russell; General Secretary, Prof. James P. Kendall ; Secretaries to Ordinary Meetings, Prof. R. J. D. Graham, Prof. W. M. H. Greaves; Treasurer, Sir Ernest Maclagan Wedderburn; Curator of Library and Museum, Dr. John E. Mackenzie; Councillors, Dr. Robert Camplell, The Right Hon. Lord Cooper, Prof. E. W. H. Cruickshank, Sir J. Donald Pollock, Mr. Stanley Cursiter, Dr. Douglas Guthrie, Prof. J. W. Heslop Harrison, Mr. Andrew W. Young, Prof. E. T. Copson, Lieut.-Col. W. F. Harvey, Prof. A. E. Trueman, Prof. John Walton.

\section{Announcements}

THE following doctorates of the University of London have been conferred : D.Sc.: Mr. B. Katz, of University College; Mr. H. G. Wells, an external student; D.Sc.(Eng.): Mr. G. Hughes, an external student; Prof. A. F. C. Pollard, University professor of (mechanical) instrument design, Imperial College of Science and Technology; D.Sc.(Econ.): Mr. R. G. D. Allen, University reader in statisties, London School of Economics.

A Discussion on "The Tetrapyrrolic Pigments" will be held by the Biochemical Society on November 13, beginning at 11 a.m. The meeting will be held in the Department of Organic Chemistry, Imperial College of Science and Technology, London, S.W.7. Further particulars can be obtained from Dr. W. Robson, King's College, Strand, London, W.C.2.

ThE Pharmaceutical Journal has issued a pamphlet entitled "A Glossary of Terms used in Sex Hormone Therapy". The introduction explains that most of the human hormones, excepting adrenalin, are either proteins, protein derivatives or steroids, and a brief description of the nomenclature of the steroids is given. The Glossary will be useful to those who cannot make a special study of this field of work and who have little time to find a way: through the maze of names in hor mone literature.

MANUFACTURers of insulin, in consultation with the Diaketic Association, have decided to standardize the colour and style of the packings, so that in future type and strength will be uniform irrespective of maker. Steps have also been taken to eliminate unnecessary deterioration in pancreas during transit from cold storage to manufacturing plant. The number of diabetics in Great Britain shows a yearly increase, and is now estimated at 200,000 , but they do not all take insulin. The Ministry of Supply states that adequate supplies of insulin have been ensured bo th for the home inarket and for liberated countries.

A Million dollars has been set aside by the Council for the Promotion of Science and Technology in China as cash awards for solutions of national defence seientific problems. The Council for the Promotion of Science and Technology has selected ten special industrial and scientific problems for consideration. Chinese men of science, industrial technicians and research workers are invited to engage in studies and research on these problems and submit reports of their results to the Council before the end of the current year. 